\title{
Contemporary Civilization Challenges in The Light of The Security Challenges of European Countries on The Example of Poland
}

\author{
Katarzyna ŚWIERSZCZ \\ Military University of Technology in Warsaw, Warsaw, Poland \\ katarzyna.swierszcz@wat.edu.pl
}

Received date:1 October 2019; Accepted date: 20 November 2019; Published date: 13 January 2020

Academic Editor: Daria Bieńkowska

Copyright (C) 2020. Katarzyna ŚWIERSZCZ. Distributed under Creative Commons Attribution 4.0 International CC-BY 4.0

\begin{abstract}
The article is aimed at showing the values and significance of Western civilization and culture built on its foundation or rather multiculturalism (polyculturalism) in the context of contemporary challenges of state security. Special attention should be paid to the threats resulting from reductionist and superficial understanding of polyculturalism currently called multiculturalism built on the foundation of globalism and the policy developed within its framework. The analysis of the problem undertaken in the field of philosophical cognition may be used not only for cognitive purposes, but also to enable the assessment and determine the scale of this phenomenon in the context of the good of man, society, nation and state. It should also contribute to the affirmation of the natural communities of human life and the human culture created within it. It has a significant meaning for proper nature of political activity of Western civilization, which due to the cognitive errors, may direct the state policy on the wrong paths and lead it to destruction. The author used analytical and synthetic research method as well as inference in the article to achieve the above assumptions.
\end{abstract}

Keywords: Western Civilization, Culture, Polyculturalism, Multiculturalism, State Security, National Security

\section{Introduction}

The Western civilization and the associated culture, being the foundation for building Europe, has been one of the most important pillars of state security for centuries and confirms its identity and strength. In the last decade, abundant in the development of technicalization and cybernetization of life as well as chaos and ineptitude in organizing social life at the same time; globalization, the bloom of production and, simultaneously, the misery of large continental areas; the bloom of the world of culture and the simultaneous

Cite this Article as: Katarzyna ŚWIERSZCZ (2020)," Contemporary Civilization Challenges in The Light of The Security Challenges of European Countries on The Example of Poland" Journal of EU Research in Business, Vol. 2020 (2020), Article ID 146710, DOI: 10.5171/2020.146710 
vulgarization of its forms; the bloom of religious life with a simultaneous return to atheism, materialism and consumption; free movement across national borders, both within the framework of European integration and in transatlantic relations there is an unprecedented diffusion of cultural phenomena, often referred to as global culture, polyculturalism or multiculturalism.

These phenomena, despite not being new, presently pose a serious threat to the state security, both in the non-military and military dimension. The strength of these processes, especially their consequences, vary in different areas. While in the United States, polyculturalism, based on diverse ethnic groups was an immanent feature of this continent from the beginning, however, in Europe, nation states were created on the basis of a common language, homogeneity of culture and the concept of nation. Therefore, while emigration, which is the main source of multiculturalism (polyculturalism), is a natural phenomenon in the United States, for Europe it is a complex and even dangerous political, cultural, economic and social process. As the reality shows, migration processes (especially illegal), the influx of communities from the poor South countries, especially from those with a completely different culture (psychocultural differences): customs, religion, values and norms - pose various serious problems and even threats. What is more, it appears that uncritical openness to this culture, with sometimes extremely different attitudes and behaviors, is often the reason of wars and conflicts based on the fight for identity in the areas of civilization circles. The threat of these conflicts is still growing, the more so because they facilitate the activity of undesirable elements, religious fundamentalists, criminal groups, operating in the sphere of the economy, trade in arms, drugs, human trafficking, and even turn into a form of terrorism.

\section{Value and Significance of the Culture}

Nowadays, there are a lot of descriptions and definitions of culture, all of which (regarding its methodological and essential scope) pay attention to different cultural aspect emphasizing its phenomenon. For instance, definitions emphasizing historical aspect refer to such terms as: cultural heritage, achievements, cultural resources or monuments and cultural monuments. In this approach, culture is understood as a set of social facts common to many human groups, or as a whole of elements of the achievements of a specific society (Czaja 2013). Definitions emphasizing the normative aspect refer to human behavior and lifestyle recognized in moral and cultural terms, highlighting their unity and uniqueness among different cultures. In this approach, culture is defined as created and transmitted content and patterns of values, ideas and symbols (signs) that play an important role in social communication, shape its behaviors and products of these behaviors (Świerszcz 2016). Definitions paying attention to the humanistic aspect, in the description of culture, the affirmation of the human spirit and the phenomenon of human freedom through which one has the ability to formulate objectives and shape higher values that have universal meaning and value (Kant 1964). In this meaning, culture is a value shaped in the process of historical development as a communal form of expression, arising as a result of cognition and values shaping the life of a specific community. It is an attempt to understand the world and human existence in the world, built not on the basis of pure theory, but on the basis of inspiring fundamental human interest in existence (Ratzinger 2005). In turn, definitions emphasizing the personalistic aspect say about culture as the shape and content of human life and the way one lives. In this meaning, culture is defined as a value by which a man as a man becomes more human, more "is" and has greater access to "existence". Such understood culture was expressed by Saint John Paul II, who often said that everything that one "has", is important for culture, it is culture-forming, if a man, through what he or she has, can at the same time more fully 
"be" a man, become more fully a man in all his or her dimensions of existence (John Paul II 1980). In this meaning, culture is a challenge and a commitment to "(...) lead a man to one's full realization as a being that transcends the world of things. (...) Culture should also not allow man to be destroyed by science and technology, which remain on the services of greed for violence, exerted by human hostile and exploiting authorities. This requires from people creating culture to be both credibly competent, and have a clear and wellestablished moral awareness, thanks to which they will not have to submit their activities to <apparent imperatives> that dominate today"(John Paul II 1999). Having this in mind, Pope John Paul II elsewhere says: "It is undoubted that the primary and basic cultural phenomenon is the man himself or herself, spiritually mature, or fully educated, able to educate himself or herself and others. It is also undoubted that the primary and basic cultural dimension is healthy morality: moral culture" (Jan Paweł II 2000). What culture is and should be, Saint John Paul II, the Pope, reminded many times in various places of his pilgrimage all over the world. Because of significance of these words, it is worth referring to several of them. The Pope has always emphasized that culture is a property of man, which means that it derives from a human being and exists for a human being. Culture in the first approach as a "human property" means that only man is the creator of culture, as a rational and free being is an active entity evaluating and creating values through which he or she confirms, develops and perfects himself or herself. These values include not only material wealth, such as: works of art, technology, means of communication, etc., but also internalspiritual wealth, such as: language, customs, ethos, social forms of human life (family, nation, state, school) and many others. Culture is, therefore, a specificity of man, a way of his or her existence, it is closely related to his or her personal life, from interior of which he or she grows (Świerszcz, Bożjewicz and Jędrzejko 2015). It is a manifestation of human nature or its potency. And as such, it is a commitment and obligation to human and somehow set.
Its quality, durability and perfection depend on the person. It is his or her Sein and Sollen. Such understood culture from its essence serves (or should serve) to the entire human and every human which represents its universe. At this point, it should be noted that at the basis of the unilateral or even primitive concept of culture, there is always a reductionist concept of a man, blurring the full and rich image of him or her as a person. Thus, there is a cultural crisis having its source in the human crisis as a cultural subject (Świerszcz 2016). Culture in the second approach as a value "existing for human" means that man is not only a creator of culture, but also is its main recipient and target. Artifacts are not the subject of culture, but a man. Everything that exists comes from man and is turned to man. The measure of all works of culture must therefore be their reference to the whole man. When talking about a man, we should consider those dimensions of human life which in a significant way need improvement, which they are inherently unable to achieve. So if you point to any areas of culture, you should always refer them to the spheres (dimensions) of a personal life. These fields are the following: science, meaning the ability to learn the truth in a methodical, verifiable and intersubjectively communicable manner; morality, meaning the ability to realize good in personal, family and social life; and finally, the output, or effects of the rational - based on realism, not reductionism human activities, different from the action as an action itself (Encyclopedia 2011). Therefore, the only criterion estimating culture (cultures) is a person, i.e. his or her full, integral (material and spiritual) growth that should be the main target of every culture according to the Saint Thomas Aquinas: "Omnes autem scientiae et artes orddinantur in unum, scilet a hominis perfectionem, quae est eius beatitdo" (Thomae de Aquino 1950).

The brief overview of culture definitions in the various aspects mentioned above clearly points to two important issues. Firstly, the definitions of culture, especially the humanistic and personalistic ones, point to the organic and durable 
connection of culture with human nature. This shows that authentic culture has a humanistic dimension, i.e., it is the work of a man with a view to a man. It is conscious shaping of human nature and environment where he or she lives, targeted at a good of human himself or herself. This good is first of all a comprehensive and integral development of a human person, which consists of the following dimensions: biological, intellectual and cognitive, volitional, moral, ethical, aesthetic and religious. The only principles that should be the foundation of culture (culturecreation) and should guide it are: the principle of truth - in the field of science and cognition; the principle of good and loving good (individual and common) - in the field of ethics, policy and economy, and the principle of final happiness (holiness, perfection) - in the field of personal life (Maryniarczyk 2014; Świerszcz, Jędrzejko and Bożejewicz 2014). Secondly, the definitions of culture clearly show that this concept had in the history and still has various meanings connected with particular consequences. Its way of understanding is entangled in various philosophical systems (streams) and sometimes ideologies connected with them (from materialistic, skeptical, nihilistic, agnostic, pragmatic to humanistic and personalistic) representing different (often contradictory) concepts of values, through the prism whose understanding and meaning of culture acquires different content - more or less enriching man and the surrounding reality.

\section{Multiculturalism or Polyculturalism and their Consequences for State Security}

Multiculturalism is often identified with polyculturalism, which is a serious abuse and even a substantive mistake. Polyculturalism should be understood as the existence of many different cultures that respect and enrich each other. In Poland this phenomenon is not new. It is confirmed by its rich history showing that even in the times of the First and Second Polish Republic there lived communities of various nationalities, such as: Lithuanians, Ukrainians, Germans, Jews, Armenians, Tatars, Karaims, Gypsies, Vlachs, the Dutch and many others, who had their own separate culture, religion and the right to express it (Różycki and Sadłocha 2014).

Contemporary concept of polyculturalism has a slightly different meaning than before, because it is mainly connected with globalism, which proclaims a vision of universal (for all humans) culture referred to as multiculturalism. On the one hand, this ideology assumes that all historical cultures are equivalent, and thus equal in terms of quality, perfection, and culturecreating power. From practical point of view, as D. Miller and famous expert on civilization issues J. Maritain say, this ideology rejects a homogeneous model of culture as a social phenomenon, contrasting it with a heterogeneous cultural conglomerate, which combines very different, sometimes even opposite, patterns and national traditions. In this sense culture is of an aspect, not a substantial nature, which means that it is no longer an inalienable property of individuals and social communities, but becomes a heuristic tool (Świerszcz 2008, Świerszcz 2004).

On the other hand, this ideology, within the top-down political and administrative actions guided by political correctness, based on statutory law, deprived - due to cultural pluralism - of all moral principles and cultural foundations - aims at lowering (weakening) and even eliminating dominant (historical) cultures expressing the identity of a given nation, its traditions in favor of other cultures of ethnic minorities, especially non-European and non-Christian cultures. In Western countries, which are mostly historical, this policy is beginning to take an increasingly anti-western character. Basic values developed within the European culture, such as: truth, goodness, beauty, freedom, love, responsibility, justice - directed in relation to the way of understanding (concept) of man, family, society, state and even God become the target of attacks (Jaroszyński 2010). This phenomenon is eloquently described by M. Phillips on the example of an observed and directly experienced war conducted in Great Britain, on a religious and cultural basis, as 
a result of a mass influx of Muslim emigrants. M. Phillips writes: "Multiculturalism allegedly promotes equal treatment of all cultures. But this is not happening. There is a culture that is not treated equally with others, and this is the local British culture. The alleged postulate of equality is in fact aimed at a radical deconstruction of the majority culture, the concept of the nation itself and the values associated with Western democracy, especially its proper understanding of morality and truth. Separatism is not the greatest evil here. It is the policy of burnt land in the cultural dimension - the zero year of a new secular era, the universal order of the world in Great Britain. Moral, cultural and spiritual emptiness resulting from such assumptions - and rightly so contempt of radical Islamists who are happy to use it" (Phillips 2010).

S. Huntington warned more than a dozen years ago against such phenomena, claiming that these wars were in fact wars for identity, carried out on the basis of civilization. This phenomenon, according to him, as the culture of the nation weakens, will constantly grow and take a various shape of conflicts both in the local, national and international dimension, starting with revolutions, ordinary banditry, through the use of force, mainly in the form of terrorism - which nowadays we observe numerous examples in various parts not only of Europe, but also of the Western world (Balcerowicz 2001). These and other experiences, therefore, show that the ideology of multiculturalism cannot create a community as a communion, and especially a nation. As they are both based on common tradition and values providing unity and stability. However, it can create an egocentric community that forms primitive and poor forms of human life, with principle of "easy and pleasant life", destroying everything that is "higher", which requires greater discipline and effort. It can create a community without empathy, where the care for the order and harmony of cohabitation, concern for the quality of interpersonal relations and true unity generally disappear; a community where the concern for an ethically and politically recognized common good disappears, and thus deprived authentic interpersonal friendship involving the whole community - which results from the question of cultural continuity, abandoning its principles and values and lack of mutual knowledge and understanding of the good that is due to and valued by man. The idea of solidarity, proclaimed in multiculturalism, does not result from the affirmation of human dignity, but from the affirmation of profits, cold calculation. Therefore, the unity formed in the multicultural society is an apparent and fragile unity, treated instrumentally in order to gain strength preparing for utilitarian expansion (Skrzydlewski 2014, Świerszcz 2009). Searching for ideological sources of multiculturalism policy foundations, they may be unambiguously found in cognitive relativism and moral relativism, pragmatism combined with utilitarianism and hedonism, antihistoricism undermining the sense of tradition, and also in utopian syncretism, or finally religious eclectism, and even atheism. The naturalistic concept of man is also an important source, which brings the man to production and the attitude of consumption. Not without significance is irrationalism proclaiming the futility of human life, stimulating a man to eternal fun and constant competition with one another, as a result of which the defeated becomes a servant and a slave (Skrzydlewski 2012).

There comes the following question: What causes the failure of multiculturalism and what consequences does it bring for social life and state security? To answer this question, one first need to visualize what is the basis of every culture within the social life of a man. The rich experience of each state, especially Poland, shows that such a basis is not politics or economics, but a civilization and associated culture. It contains the most important values that shape human, social and state life, such as: Truth, Good, Beauty. They build forms of social relations starting from the family, through various smaller communities, and ending with the largest community that is the state. These values, although sublime, can be understood and realized in different ways, just as different is the way of 
understanding and realizing culture. This difference has its source in civilizational diversity (e.g. Byzantine, Turanian) understood as a method of social life system. It results in a diversity of principles and values, a way of understanding reality and many other areas of human life, whose differences may reach very deeply and be the reason of many conflicts and even wars - Europe is becoming increasingly clear example of it (Jaroszyński 2014). It shows that cultural unity, state unity cannot be built if there are civilization differences between the cultures and associated differences in values. As these differences are mutually exclusive, leading to the dominance of one civilization over the other and analogically one culture over the other. What is more, such understood culture is reduced to the level of myth and utopia, which deprive it completely of what it was originally and should be today. The Spanish thinker, J. Ortega y Gasseta, formulating a diagnosis of contemporary European culture, says clearly about its progressive degeneration in the axiological order, about the danger of cultural and social anomie associated with a deep and multifaceted crisis. "Europe has faced a serious crisis (...). Europe has been desocialized, in other words, it is in a situation where there are no existing rules of cohabitation that can be referred to." In another place, he says: "All the principles from which European culture draws lifegiving juices, such as: politics, law, art, morality, religion (...) are experiencing a crisis, being - at least temporarily - in a fall" (Ortega y Gasset 1982). In the context of this statement, it is worth referring to the reflection of the world-famous German philosopher, E. Husserl, reminding us that: "if common idea of truth itself becomes a universal norm of all relative human truths (...) and alleged situational truths, then this also applies to all traditional norms, norms of law, beauty, purpose, dominating personal values, etc." (Husserl 1993). If the opposite happens, i.e. the truth does not define the sense of human and society existence, then it results in a crisis of values and, subsequently, a crisis of humanity and the whole of culture. Referring to the thought of W. Jaeger, it can be said that contemporary culture in the form of multiculturalism is not a "paideia" (upbringing) any more, but "extended in infinity and anarchically external " apparatus of life » kataskeue tu biu that much more seems to need to radiate its inner primary sense (to ensure if it has any sense at all) than to be able to give some value to what it has evolved from" (Jaeger 2001; Świerszcz 2015). If the culture of Europe wants to be what it was originally, it must free itself from idealism and irrationalism error and their ideological consequences, which are modernism and postmodernism. Idealism and reality and ideology and culture cannot be reconciled with each other. What is more, a real person loses on their merger, becoming the object of ideological manipulation, while one's culture becomes an anti-culture, turning against its creator. Thus, multiculturalism as an ideology undermines the sense of culture. The theses proclaimed by it are internally contradictory and incompatible with the natural experience which shows that cultures are not equivalent or qualitatively equal. It is hard to recognize as such the cultures arisen from the totalitarian system, which treat man objectively - with cultures arisen from the Western (Latin) civilization, which treat human beings subjectively, in terms of human inviolable dignity. A meaningful confirmation of this is the personal experience of everyday life as well as historical experience at the national and international level. Nowadays, the most bright manifestations of crises at various levels are terrorist attacks starting with the World Trade Center through assassinations in London, Madrid, Paris or various cities in Germany (Kiereś 2015, Świerszcz 2012).

\section{Western Civilization as a Space of State Security}

The Western civilization grew on three historical pillars: Greek philosophical thought - starting rational knowledge; the Roman concept of law - giving priority to natural law and the Christian vision of man - revealing the two-dimensionality and integrity of the human person. The synthesis of these three components created in the history a new quality, which 
was called the Western civilization (also referred to as Latin civilization, personalistic civilization) or European culture. What is the phenomenon of the Western civilization quality, opening the space of culture, the culture of purpose as a space of state security: shaping its identity, existence and development? To answer this question, we need to begin with defining the Western civilization and the features distinguishing it from other social projects. The Western civilization in the view of the famous researcher and an expert in various civilizations F. Koneczny, is defined as a method of "arranging collective life", that is the system of social life based on five general but the most important values within which the whole individual, social and political life is shaped and implemented, such as: truth, goodness, beauty, health and welfare. These values include basic features (properties) characterizing not even the civilization, but mostly the reality. Having this in mind, it can be noted that the values in the tradition are described as transcendentalia, i.e. properties of being as being. In this sense, truth is understood as the compatibility of cognition with reality; good is understood as the compatibility of inclination with the real goal, and beauty is understood as the compatibility of love and cognition with real perfection and harmony. Each of these transcendentalia is judged by the reason able to reach reality, exceeding any limitations of a civilization or a culture developed within its framework (Jaroszyński 2014, Świerszcz 2012). These values, as F. Koneczny notices, due to their features, are foundation for Western civilization structuring the life of human community. What is more, they are axiological plane, on foundation of which considering specific means and goals of their foundation - collective, individual, social and political life is organized (Koneczny 1996).

The need of forming civilization, similarly like culture, is nothing new. At every stage of one's development, human takes actions to strive to create an environment enabling him or her, and even helping him or her to realize oneself as a rational and free creature, to shape and realize one's humanity, as well as to cultivate the values he or she chooses. Not without reason, S. P. Huntington says clearly that the history of mankind is the history of civilizations, because in their space, the civilizations provided the greatest opportunities for people to develop their own identity (Huntington 2001). In this place it should be noted that man does not create the civilization alone, but always in the context of specific community with whom he or she is connected by particular relations forming a community and its identity. The number of methods of the collective life system is, therefore, unlimited, because the number of different ways of building and creating civilization systems is unlimited. Their mutual arrangement (such and not other) determines the quality of civilization and the degree, as well as the method of building social relations.

What distinguish the Western civilization from other social project and indicate its quality as the basis for the area of state security is the culture of purpose in which the category of the common good or, to be more precise, the degree and manner of social security of the common bonum commune. And here comes the next question: What is the common good of the Western civilization? The answer is unambiguous. Common good of Western civilization is the good of human understood as a Person, i.e. psychophysical being (bodily and spiritual); good of every human; only human and always human. The man is seen in terms of five complementary purposes that penetrate his or her life, both personal and material, which are mentioned above: truth, good and beauty, that is science, morality, religion and art, as well as health and welfare. The social life is also built on these values, which is expressed by the primacy of the law of nature over the statutory law (positive) and civil law over the state law. Thus, it can be noted that this is a personalistic apothecary and organic civilization that recognizes the transcendent (in relation to civilization) dignity of every human being along with one's rights. The reference point of Western civilization is the affirmation of human dignity as a human being, which is 
also reflected in the affirmation of human basic rights, including the right to live in society, it means, in a specific civilization. This civilization refers to the experience of what is permanent and what cannot be changed - posing the threat of changing the type of civilization - being able at the same time to self-control what is variable in changing living conditions, so-called devices.

Another factor distinguishing Western civilization and at the same time constituting its foundation is realism, having its source in an autonomously practiced philosophy understood as love for the sole truth, reaching with its roots the thoughts of Aristotle and Saint Thomas Aquinas. This fact shows that Western civilization is not a myth or utopia, or even the ideology of a specific time and specific individual; it is not a contractual assumption. Being based on the foundation of autonomous classical philosophy as theoretical wisdom, being the only selfaware science disinterestedly devoted to the truth, taking on the responsibility of being an ancilla culturae, that is the handmaid of culture, culture of purpose - it serves the common good of man's life (material and personal/spiritual) in wisdom practical, revealing the real status of being which is a man-person (regardless of civilization) and the surrounding reality (Kiereś 1998; Filipek 2006).

Polish culture is its clear example which is a kind of phenomenon that from the very beginning, that is from the moment the Polish state was formed and from the date of its baptism, crystallized above all on the basis of Western civilization (Latin civilization). It was the Western civilization that determined the crystallization of Polish culture, decisive for the identity of this country, its strength and wisdom. It should be remembered, however, that the other three civilizations present on its territory, such as Byzantine, Turanian and Jewish, also had a major impact on the culture of Poland and, subsequently, on its history. Those civilizations were mostly imposed with force, sometimes reaching the fertile ground in various environments used by other countries for their interest or to strengthen them (Encyclopedia 2011). Therefore, facing contemporary unrest in the context of state security, both in the internal and external, domestic and international dimension - resulting from the clash of various civilizational influences and related cultures (the world of values) it can be certainly stated that only the Western civilization is able to meet these challenges. It results from the fact that only Western civilization is a personalistic civilization underlying personalistic (humanistic) culture, fully open to human. Only in it, a personal being, which is a human being affirms. Only it says about human as a person, so someone with own dignity, rights and freedom recognized in the context of integral truth about the human as a psychophysical (i.e. bodily and spiritual) person.

At this point, it can be noticed that thus realized purpose-culture-oriented Western civilization, whose purpose is a human being - is the basis for the identity and development opportunities of not only the person but also the nation creating it. Culture is primarily connected with the life of the nation. It was emphasized many times by St. John Paul II during his pilgrimages in various countries. During his visit in UNESCO, he particularly emphasized the relationship between culture and the nation, its sovereignty and national identity, saying: "The nation is a great community of people, which are connected by various binders, but above all, there is culture. The nation exists «from culture» and «for culture». And therefore, it is the significant educator to "be more " in a community that has a longer history than a man and his family. (...) Nations exists as a truly sovereign entity thanks to its culture. It allows the nation to survive even when there are no structures of a sovereign state that we have experienced in our own history. (...) I am the son of a nation that survived the most terrible experience of history, whose neighbors repeatedly condemned it to death - and it remained alive and remained itself. It kept his own identity and sovereignty as a nation during the partitions and occupation considering only culture as the basis for the survival, not any 
other means of physical power, which, in this case, turned out to be greater than the powers. Therefore, what I am saying here about the rights of nations that have emerged from the foundations of culture and that are moving towards the future is not an echo of any "nationalism», but remains a permanent element of human experience and humanistic perspectives of a man. There is a basic sovereignty of societies that is expressed in the culture of the nation. Simultaneously, it is the sovereignty that makes the man the most sovereign at the same time" (John Paul II 2005). The Western civilization as a culture of purpose is such a civilization which, based on realism, creates the proper space and climate for the existence of multinational societies and their national cultures, in which man can develop the fullness of his or her humanity, enriching with their spiritual and personal good, meaning the one that builds man as a man. In this sense, Western civilization is the one, which in the most authentic way shapes real space for state security, while being responsible for the culture content and quality at the same time.

Another significant factor distinguishing the Western civilization from other civilizations, constituting the possibility of creating a state security space, is openness to polyculturalism and openness to various civilizations. This openness, however, is conditioned by respecting the basic values and principles that are granted to man as a man (person). They mean anthropological criteria related to the fact of being a man, not the criteria of civilization. Lack of this anthropological criterion (foundation) leads inevitably sooner or later to the fight of cultures - not always evident. Cultures without a civilizational basis built on the foundation of anthropology are subject to destruction, and the appearing fight between them takes the form of a struggle for survival or will to dominate. In such case, there is no fight for realization of purposes or great ideals. It results in civilization chaos, whose natural consequence is the chaos of social life. Therefore, in order not to let one culture destroy another, there must exist the above-mentioned values and principles, respected by different cultures. The West civilization seems to be the ground for this, as it is the only civilization indicating such values and principles, going beyond the civilization, including itself (Jaroszyński 2014; Świerszcz 2004; Włodarczyk 2018). This is what makes it the most rich.

\section{Conclusion}

The influence of culture on the quality and level of security and the related challenges are one of those issues whose significance nowadays, in the era of globalism, open borders and increased migration, is constantly growing. The process of globalization having a tendency to universalize and unify cultural patterns (global patterns), evokes natural reactions of national cultures, striving for affirmation and protection of own identity, national heritage, and emphasizing own individuality and richness of values in the conditions of openness to the world. A new look at security and international relations through the prism of culture and cultural aspects - including polyculturalism and multiculturalism - clearly shows that what constitutes a significant threat today is polyculturalism outside of civilization, referred to as multiculturalism. It means lack of a common civilization for different cultures, which prevents the mutual coexistence of cultures and mutual complementarity. Building a universal culture to create a platform for the security of state, nations and Europe is fiction and utopia. A deeper understanding of culture as a way of being a human, building a social community, national identity, which naturally translates into a way of organizing social, it means civilization, life shows that the differences between them can be and are the reason for many conflicts and wars. The rich experience of each state, especially Poland, shows that the real basis for building the space of state security, effectively facing its contemporary challenges is primarily the Western civilization and its culture, purpose-oriented culture. It contains the most important values that shape human, social, national and state life, such as: Truth, Good, Beauty. They build forms of social, national and international relations. 
All other solutions in the form of multiculturalism, although seem to be sublime and beautiful, in isolation from realities, are a serious mistake and an absurdity.

\section{References}

1. Balcerowicz, B. (2001), Pokój i niepokój, Bellona, Warszawa.

2. Czaja, J. (2013), Kulturowy wymiar bezpieczeństwa. Aspekty teoretyczne i praktyczne, AFM, Kraków.

3. Encyklopedia Filozofii Polskiej (2011), Maryniarczyk, A. (ed), KUL, Lublin.

4. Filipek, A. (2006), Tożsamość kulturowa i wartości cenione przez młodzież na przełomie XX i XXI wieku, Konflikt pokoleń czy różnic cywilizacyjnych. Wzory i wartości aktualne i unieważnione, cz. 1., Zacharuk, T. (ed), UPH, Siedlce.

5. Huntington, S. P. (2001), Zderzenie cywilizacji i nowy kształt ładu światowego, PWN, Warszawa.

6. Husserl, E. (1993), Kryzys europejskiego człowieczeństwa a filozofia, Aletheia, Warszawa.

7. Jaeger, W. (2001), Paideia, Fundacja Aletheia, Warszawa.

8. Jan Paweł II. (1999a), Przemówienie w siedzibie UNESCO, 2.06.1980, Uniwersytety $\mathrm{w}$ nauczaniu Jana Pawła II, Urbański, S. (ed), WSZiP, Warszawa.

9. Jan Paweł II. (1999b), Rola Uniwersytetów w tworzeniu nowego społeczeństwa. Spotkanie $\mathrm{z}$ Profesorami i studentami uniwersytetu Kolumbii, 5.07.1986, Uniwersytety w nauczaniu Jana Pawła II, Urbański, S. (ed), WSZiP, Warszawa.

10. Jan Paweł II. (2000), Wychowanie jest pierwszym i zasadniczym zadaniem kultury. Przemówienie w Siedzibie Organizacji Narodów Zjednoczonych do Spraw Oświaty, Nauki i Kultury (UNESCO), Paryż, 2.06.1980 r., Wychowanie $\mathrm{w}$ nauczaniu Jana Pawła II, Urbański, S. (ed), WSZiP, Warszawa.

11. Jaroszyński, P. P. (2014), 'Multikulturalizm - poza cywilizacją?,' Człowiek w kulturze. Cywilizacja wobec multikulturalizmu 24, 5-16.

12. Kant, I. (1964), Krytyka władzy sądzenia, PWN, Warszawa.
13. Kiereś, H. (2014), 'Uwagi w sprawie kryterium ocen kultury - w związku z tzw. multikulturalizmem,' Człowiek $w$ kulturze. Cywilizacja wobec multikulturalizmu 24, 29-35.

14. Kiereś, H. (1998), Służyć kulturze, Instytut Edukacji Narodowej, Lublin.

15. Koneczny, F. (1996), 0 cywilizację łacińską, KUL, Lublin.

16. Maryniarczyk, A. (2014), 'Osoba a wielokulturowość,' Człowiek $w$ kulturze. Cywilizacja wobec multikulturalizmu 24, 17-28.

17. Ortega y Gasset, J. (1982), Bunt mas i inne pisma socjologiczne, PWN, Warszawa.

18. Phillips, M. (2010), Londonistan. Jak Wielka Brytania stworzyła państwo terroru, Sprawy Polityczne, Warszawa.

19. Ratzinger, J. (2005), Wiara-prawdatolerancja. Chrześcijaństwo a religia świata, Jedność, Kielce.

20. Różycki, M. and Sadłocha, J. (2014), Multikulturalizm i bezpieczeństwo. Dla kogo różnorodność stanowi zagrożenie?, Konflikty etniczne i wyznaniowe a problem bezpieczeństwa we współczesnym świecie, Jarząbka, J. and Szyszlaka, T. (ed) NOMOS, Kraków.

21. Ryba, M. (2014), 'Multikulturalizm w Europie Zachodniej - historia i teraźniejszość,' Człowiek w kulturze. Cywilizacja wobec multikulturalizmu 24, 37-53.

22. Thomae de Aquino S. (1950), Sententia libri Metaphysicae, premium, Taurini.

23. Skrzydlewski, P. (2014), 'Ideologie wielokulturowe a destrukcja polityki Zachodu,' Człowiek $w$ kulturze. Cywilizacja wobec multikulturalizmu 24, 72-89.

24. Skrzydlewski, P. (2012), Kolektywizm, indywidualizm a osobowa wizja człowieka, Spór o osobę w klasycznej koncepcji człowieka, Mazur, PS. (ed), Kraków.

25. Świerszcz, K. (2016), Integralne wychowanie na rzecz integralnego bezpieczeństwa - jako naglące wyzwanie współczesnych czasów, Obronność państwa. Uwarunkowania oraz organizacja bezpieczeństwa i obronności, Trejnis, Z. and Marciniak, 
M. (ed), Adam Marszałek, Toruń. (ISBN 978-83-8019-539-4).

26. Świerszcz, K. (2012), Nauka w służbie prawdy - służbą (integralnemu) człowiekowi, Nauka polska - prawda jest najważniejsza, Boruta M. and Opiła J. (ed), AKO, Kraków. (ISBN 978-604990-61-4).

27. Świerszcz, K. (2008), 'Postęp czy zagrożenie? - Niepokoje współczesnego człowieka,' Communio 2 (162), 3-19.

28. Świerszcz, K. (2004), 'Prawda o człowieku obroną przed iluzjami,' Zarządzanie i Edukacja 1(43), 165-175.

29. Świerszcz, K. (2009), 'Wolność w perspektywie prawdy,' Communio, 2(166), 70-85.

30. Świerszcz, K., Jędrzejko, M. and Bożejewicz, W. (2014), Człowiek w ponowoczesności - postęp czy zagrożenie?, Młode pokolenie w zderzeniu cywilizacyjnym. Studia badania - praktyka, Jędrzejko, M. and Malinowski, JA. (ed), AKAPIT, Toruń. (ISBN 978-83-63955-18-2).

31. Świerszcz, K., Bożejewicz, W. and Jędrzejko, M. (2015), „Inżynieria społeczna” człowieka w epoce postmodernizmu i jej implikacje, „Zwariowany” świat ponowoczesności, Jędrzejko, MZ. (ed), ASPRA-JR, Warszawa-Milanówek. (ISBN 978-837545-635-6).

32. Włodarczyk, E. (2018), Edukacja dla bezpieczeństwa, Wasiuta, O., Klepka, R. and Kopeć, R. (ed) Vademecum bezpieczeństwa, Libron, Kraków. 